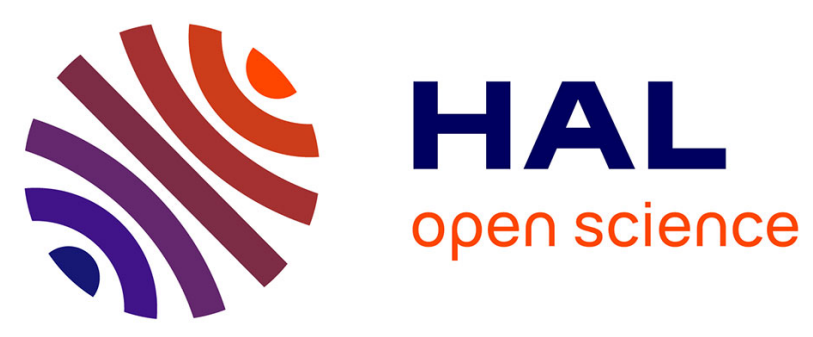

\title{
Successful resolution of pneumonia developed in a patient affected by Crohn's disease, rheumatoid arthritis, myasthenia gravis and recurrent uveitis during concomitant treatment with tumour necrosis factor $\alpha$ inhibitors and conventional immunosuppressive drugs
}

Erika Angelucci, Monica Cesarini, Piero Vernia

\section{To cite this version:}

Erika Angelucci, Monica Cesarini, Piero Vernia. Successful resolution of pneumonia developed in a patient affected by Crohn's disease, rheumatoid arthritis, myasthenia gravis and recurrent uveitis during concomitant treatment with tumour necrosis factor $\alpha$ inhibitors and conventional immunosuppressive drugs. Rheumatology International, 2009, 30 (7), pp.977-978. 10.1007/s00296-009-1012-6 . hal-00568299

\author{
HAL Id: hal-00568299 \\ https://hal.science/hal-00568299
}

Submitted on 23 Feb 2011

HAL is a multi-disciplinary open access archive for the deposit and dissemination of scientific research documents, whether they are published or not. The documents may come from teaching and research institutions in France or abroad, or from public or private research centers.
L'archive ouverte pluridisciplinaire HAL, est destinée au dépôt et à la diffusion de documents scientifiques de niveau recherche, publiés ou non, émanant des établissements d'enseignement et de recherche français ou étrangers, des laboratoires publics ou privés. 
Successful resolution of pneumonia developed in a patient affected by Crohn's disease, rheumatoid arthritis, myasthenia gravis and recurrent uveitis during concomitant treatment with tumour necrosis factor $\alpha$ - inhibitors and conventional immunosuppressive drugs.

Erika Angelucci, MD; Monica Cesarini, MD; Piero Vernia, MD; Enrico Corazziari, MD. Gastroenterology Unit, University of Rome "Sapienza”, Rome, Italy

Address for correspondence:

Erika Angelucci, MD

Gastroenterology Unit

University of Rome "Sapienza"

Viale del Policlinico 155, 00161

Rome, Italy

Mobile: +39-388-6936725

Mail: erika.angelucci@yahoo.it 


\begin{abstract}
Tumour necrosis factor alpha inhibitors, both infliximab adalimumab, have been approved for the treatment of both rheumatoid arthritis and Crohn's disease. A slight increase in the risk of infections in patients receiving immunosuppressants and/or biological agents has been reported. Here we present the case of a 68- year-old woman affected by Crohn's disease, myasthenia gravis, recurrent uveitis and rheumatoid arthritis who developed pneumonia successfully during concomitant treatment with biological agents and conventional immunosuppressive drugs.
\end{abstract}


A 68- year-old woman affected by myasthenia gravis, recurrent uveitis, rheumatoid arthritis (RA) and gallstones developed in the first months of 2003 diarrhoea (about 5-6 intestinal movements for day, without blood) and abdominal pain. At that time the patient was treated by systemic corticosteroids (prednisone $10 \mathrm{mg} /$ day) and non steroidal antinflammatory drugs (NSAIDs) for rheumatoid arthritis, topical corticosteroids for recurrent uveitis, ursodeoxycholic acid for gallstones and cholinesterase inhibitors (pyridostigmine) for myasthenia gravis.

An ileocolonoscopy was performed showing ulcers in the terminal ileum. Histological examination of the ileal specimen showed the presence of histopathological findings suggesting the diagnosis of Crohn's disease (CD). A small intestine contrast ultrasonography (SICUS) was also performed showing thickening of bowel wall $(3.8-6 \mathrm{~mm})$ for the last $7 \mathrm{~cm}$ of the terminal ileum, supporting the hypothesis of CD. The patient was referred to our GI Unit, daily dose of prednisone was increased to $50 \mathrm{mg} /$ day and maintenance treatment with mesalazine $2.4 \mathrm{~g} /$ day was started. NSAIDs were stopped. The patient failed to taper prednsione at a dose less than $10 \mathrm{mg} / \mathrm{day}$, for the reappearance of abdominal pain in low right quadrant of the abdomen and articular pain. In November 2003, for this condition of steroid-dependancy and for the finding of osteoporosis, treatment with infliximab at a dose of $5 \mathrm{mg} / \mathrm{kg}$ at weeks 0,2 , and 6 , and azathioprine $(2 \mathrm{mg} / \mathrm{kg} /$ day $)$ was started. Steroids were withdrawn and for one year patient experienced well being, without abdominal and articular pain. Furthermore myasthenia gravis reached complete remission and neurologists stopped treatment with pyridostigmine. In October 2004 the patient was referred to Emergency Unit due to abdominal pain in the upper and right quadrants of the abdomen and vomiting. Diagnosis of acute pancreatitis was made, azathioprine treatment was stopped, due to a first hypothesis of drug-induced pancreatitis, and an endoscopic retrograde cholangiopancreatography (ERCP) with sphincterectomy and stones extraction was performed. A cholecystectomy wasn't preformed due to opposite opinion of anaesthesists. Six months later, during April 2004, for the reappearance of articular pain first and then abdominal pain prednisone $10 \mathrm{mg}$ was started again. In 2006 due to the further need of NSAIDs and due to the a recurrence of uveitis treated by topical steroids, azathioprine was started again at a dose of $2 \mathrm{mg} / \mathrm{kg} / \mathrm{day}$. The drug was well tolerated, without increase in pancreatic enzymes, but the patient failed to stopped steroids over a 2-years period, for the reappearance of articular and abdominal symptoms within 1 month by steroids withdrawal. Another SICUS was performed showing an increased length of the involved terminal ileum $(23 \mathrm{~cm}$ respect to $7 \mathrm{~cm}$ in 2003). Venous blood assessment revealed rise in the erythrocyte sedimentation rate $(\mathrm{ESR})(60 \mathrm{~mm} / \mathrm{h})$, C-reactive protein $(\mathrm{CRP})(18.4 \mathrm{~g} / \mathrm{dl})$ and 
fibrinogen (604 U/ml). In June 2008, after a negative screening by Chest X-ray and PPD, induction treatment with adalimumab was started (160 mg at week 0 and $80 \mathrm{mg}$ at week 2) followed by maintenance treatment (40 mg eow). At the beginning of September 2008 the patient stopped steroids. Two months after steroids withdrawal the patient was in well-being and venous blood assessment revealed normal value of $\operatorname{ESR}(9 \mathrm{~mm} / \mathrm{h}), \operatorname{CRP}(0.9 \mathrm{mg} / \mathrm{dL})$ and white blood count $(5$ 100/mmc). The patient continued maintenance treatment with adalimumab $40 \mathrm{mg}$ eow and azathioprine $(2 \mathrm{mg} / \mathrm{kg} / \mathrm{day})$. Few days before the $11^{\text {th }}$ injection of adalimumab $40 \mathrm{mg}$ the patient developed fever, chest pain, severe fatigue, dyspnea and non-productive cough. Patients was referred to Emergency Unit. Laboratory findings showed increase in white blood count (15 290/mmc) with prevalence of neutrophils (86\%), normal number of lymphocytes (8\%, 1 200/mmc) and increase in ESR and CRP $(45 \mathrm{~mm} / \mathrm{h}$ and $4.5 \mathrm{mg} / \mathrm{dL}$, respectively). Chest X-ray showed a consolidation in the lower left lobe (Figure 1). Pathogen agent was not identified but empirical antibiotical therapy with amoxicillin-clavulanic acid was started with success. Adalimumab and azathioprine were immediately stopped. Patient recovered in one week and Chest X-ray performed 15 days later showed resolution of lobar consolidation. However, without immunosuppressive therapy, a relapse of myasthenia with prevalence of ocular symptoms (dyplopia, decrease of visus) appeared, requiring restarting of therapy with steroid (prednisone $10 \mathrm{mg} /$ day) and azathioprine (2 $\mathrm{mg} / \mathrm{kg} /$ day). At the present time, patient is in well being under this maintenance therapy.

\section{Discussion}

Tumour necrosis factor alpha (TNF- $\alpha$ ) inhibitors, both the humanized one (infliximab) and the fully human (adalimumab) have been approved for the treatment of both rheumatoid arthritis and CD (1,2). A slight increase in the risk of infections due to prolonged immunosuppression was reported in rheumatological patients as far as in IBD patients, expecially in severe ones requiring concomitant and prolonged steroid use $(3,4)$. In particular, several cases of pneumonia, including severe cases by Nocardia Cyriacigeorgica (5), Legionella pneumophila and Pneumocysti carinii, were reported in the recent years.

On the other hand the safety of these agents on patients with myasthenia gravis has not been assessed. Only one case report showed the potential benefit coming from therapy with infliximab in one patient with myasthenia gravis, but the appearance of infectious side-effects, as in our patient, lead to withdrawal of this biological agent (6). To our knowledge this should be the first report of use of adalimumab in a patient with myasthenia gravis. 


\section{Figure Legend}

Figure 1. Chest X-ray performed at Emergency Unit showing consolidation in the lower left lobe.

\section{References}

1. Scott DL, Kingsley GH (2006) Tumor Necrosis Factor Inhibitors for Rheumatoid Arthritis. N Engl J Med 355:704-712 Medline. doi:10.1056/NEJMct055183

2. Danese S, Pagano N, Angelucci E, et al (2007) Tumor necrosis factor-alpha monoclonal antibodies for Crohn's disease: tipping the balance. Curr Med Chem 14:1489-1497 Medline. doi:10.2174/092986707780831104

3. Bonghartz T, Sutton AJ, Sweeting MG, et al (2006) Anti-TNF antibody therapy in rheumatoid arthritis and the risk of serious infections and malignancies: systematic review and metaanalysis of rare harmful effects in randomized controlled trials. JAMA 295:2275-2285 Medline. doi:10.1001/jama.295.19.2275

4. Lichtenstein GR, Feagan BG, Cohen RD, et al (2006) Serious infections and mortality in association with therapies for crn's disease: TREAT registry. Clin Gastroenterol Hepatol 4:621630 Medline. doi:10.1016/j.cgh.2006.03.002

5. Parra MI, Martinez MC, Remacha MA, et al (2008) Pneumonia due to Nocardia Cyriacigeorgica in a patient wih Crohn's disease treated with infliximab. J Crohn's Colitis 2:331-332. doi:10.1016/j.crohns.2008.05.003

6. Kakoulidou M, Bjelak S, Pirskanen R, et al (2007) A clinical and immunological study of a myasthenia gravis patient treated with infliximab. Acta Neurol Scand 115:279-283 Medline. doi:10.1111/j.1600-0404.2006.00778.x 


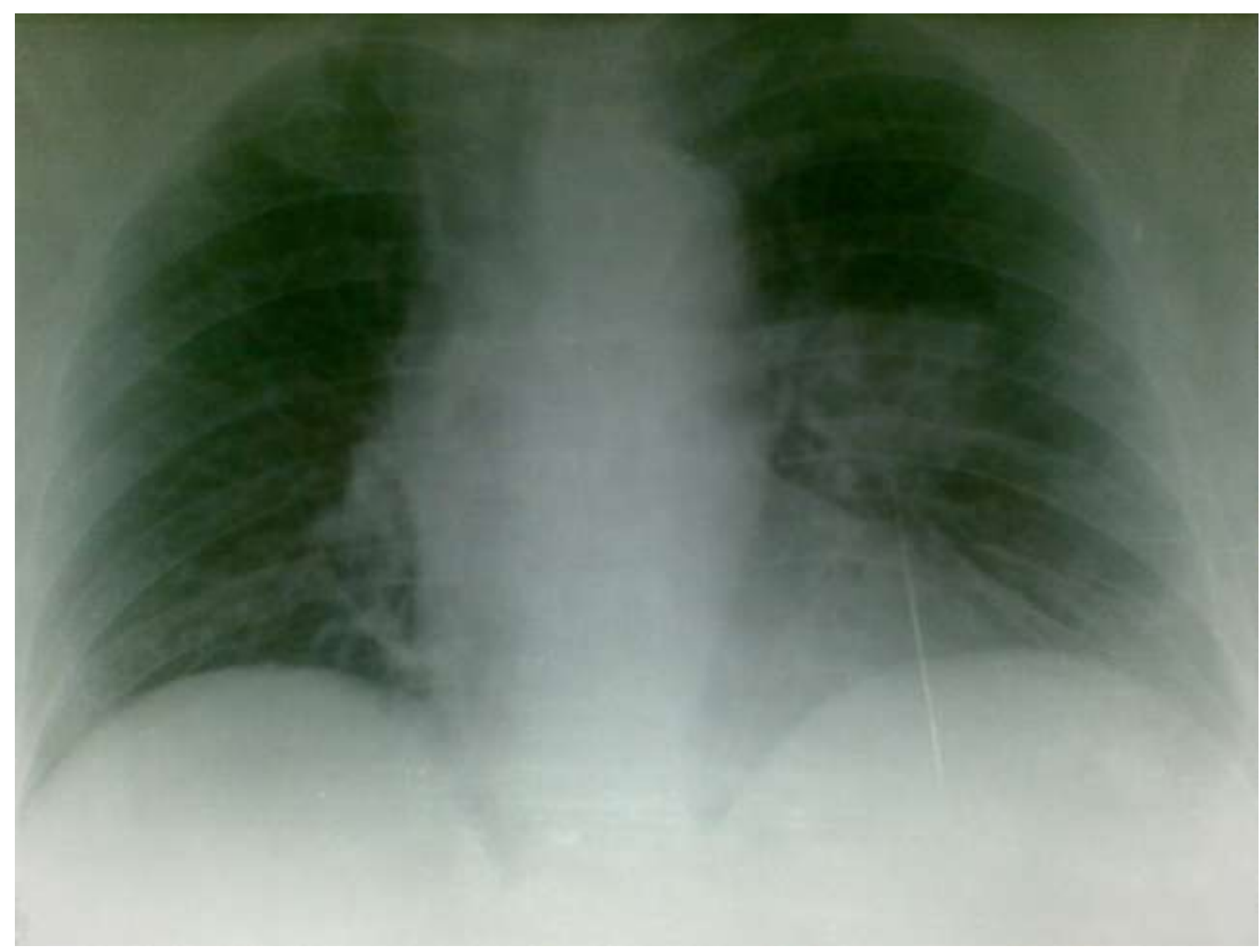

